\title{
Laboratory investigation of the strength development of alkali-activated slag-stabilized chloride saline soil ${ }^{*}$
}

\author{
Yin $\mathrm{CHENG}^{\dagger 1,2}$, Hao YU², Bao-lin ZHU ${ }^{1,2}$, Dao-xin WEI ${ }^{1}$ \\ ( ${ }^{1}$ Road Construction and Materials Research Center, China Academy of Transportation Sciences, Beijing 100029, China) \\ $\left({ }^{2}\right.$ School of Transportation Science and Engineering, Beihang University, Beijing 100191, China) \\ †E-mail: chengyin19840918@sina.com \\ Received June 19, 2015; Revision accepted Dec. 15, 2015; Crosschecked Apr. 15, 2016
}

\begin{abstract}
Saline soil stabilization is being increasingly applied in foundation treatment engineering. Chloride saline soil obtained from sites and laboratory-made chloride soil (ZS) with various $\mathrm{NaCl}$ concentrations prepared artificially were stabilized using alkali-activated slag (AS). A series of unconfined compressive strength (UCS) tests, X-ray diffraction (XRD), energy-dispersive X-ray analysis (EDXA), thermal gravity-differential thermal gravity (TG-DTG), and ion concentration tests were conducted to investigate the strength variation and mechanism of the AS-stabilized chloride saline soils. The results showed that $\mathrm{NaCl}$ has a significant influence on the strength of AS-stabilized chloride saline soil and the strength of AS-stabilized ZS (GZS) increases with increase of chloride content in soil samples. Friedel's salt (Fs) and $\mathrm{NaOH}$ are generated by the reaction of $\mathrm{NaCl}$ and $\mathrm{CaO} \cdot \mathrm{Al}_{2} \mathrm{O}_{3}(\mathrm{CA})$ in the slag in the GZS. Fs can fill the pores in stabilized soil, and $\mathrm{NaOH}$ can promote calcium silicate hydrate $(\mathrm{CSH})$ generation. These two effects combine to enhance the strength of GZS. The relationship between the rate of increase of 28-d UCS of AS-stabilized chloride saline soil and the chloride content in soil was obtained through regression analysis of the increase of UCS of GZS.
\end{abstract}

Key words: Chloride saline soil, Alkali-activated slag (AS), Stabilized soil, Strength, Friedel's salt (Fs), $\mathrm{NaOH}$ http://dx.doi.org/10.1631/jzus.A1500185

CLC number: TU472.4

\section{Introduction}

The area of saline soil in China is up to $3.6 \times 10^{7} \mathrm{hm}^{2}$ and accounts for $4.88 \%$ of the national available land area (Yang, 2008). Chloride saline soil, an important type of saline soil, is widely distributed over coastal beaches, harbors, and inland salt lakes in China. In recent years, a large area of chloride saline soil has been formed in the eastern coastal areas of China through land reclamation. The salinity of chloride saline soil is generally between $1.5 \%$ and $15 \%$, and the chloride is dominant; its strength and defor-

\footnotetext{
* Project supported by the National Natural Science Foundation of China (Nos. 51008007 and 51308266) and the Science and Technology Project on Construction of Ministry of Transport of China (No. 2013318J01100)

(D) ORCID: Yin CHENG, http://orcid.org/0000-0001-6169-7903

(C) Zhejiang University and Springer-Verlag Berlin Heidelberg 2016
}

mation modulus are poor. In recent years, some large construction projects, such as highways, ports, and nuclear power stations have been built on chloride saline soil. Therefore, the treatment of soft chloride saline soil has become an urgent and important issue.

Soil stabilization is an important technique used in saline soil foundation treatment, in which saline soil is well mixed with stabilizer and becomes stiff and stabilized (Valls and Vàzquez, 2000; Chen et al., 2009). Nowadays, most research on saline soil stabilization focuses on sulfate saline soil (Rajasekaran, 2005), and only a few studies have considered chloride saline soil. Cement is currently the major stabilizer for saline soil; however, the stabilization effect on cement-treated sulfate saline soil was unsatisfactory because of the formation of ettringite, which can swell and undermine the structure of the stabilized soil (Wattanasanticharoen, 2004). In addition, cement 
is also inapplicable to the stabilization of chloride saline soil because of the high chloride salt content in the soil (Yang, 2006). Wang and Kremmydas (1970) indicated that the strength reduction in the soilcement specimens with sodium chloride additive was because of the increasing coarseness of the additive. Luo (2009) attempted to use cement to stabilize chloride soil in the Tianjin-Binhai New Area, China; the results showed that the cement-stabilized chloride soil could not meet the engineering requirements for highway subgrade. Shihata and Baghdadi (2001) investigated the durability characteristics and compressive strengths of cemented soils after an extended exposure to chloride saline water; the results demonstrated that chloride salts have adverse effects on the durability of cemented soil. Xing et al. (2009) indicated that the chloride ions, sodium ions, and magnesium ions in chloride saline soil cause a change in the microstructures of the salt-rich cement-stabilized soil and reduce the strength of the stabilized soil. They proposed that the mixing ratio of cement must be increased to stabilize chloride saline soil of high salinity. Zhang et al. (2014) evaluated the influence of salt concentration on cement-stabilized clay by electrical resistivity measurements; the results indicated that a high concentration of chloride salt has a detrimental effect on the strength of cement-stabilized clay. These studies showed that cement is not suitable for stabilizing chloride saline soil. Therefore, finding a new type of stabilizer that is suitable for chloride saline soil stabilization is necessary.

As an industrial by-product, slag, a cementitious material, has excellent anti-salt-corrosion properties, and it can be effectively used as a stabilizer in sulfate environments (Tasong et al., 1999). Wild et al. (1998) studied the effect of partial substitution of lime with slag on the strength properties of stabilized sulfatebearing clay soils. The results indicated that the presence of slag decreases the deleterious expansion of ettringite and improves the strength significantly. Higgins (2005) summarized the research conducted in the UK and practical experience relating to the use of the combination of slag and lime for sulfate soil stabilization, and indicated that slag and lime stabilization is becoming the preferred option when a lot of sulfates are present in the soil. These studies focused on the application of slag to sulfate saline soil; however, no study has been reported on the application of slag to stabilize chloride saline soil and so the ap- plicability of slag to chloride saline soil is unclear. Therefore, in this study selected chloride saline soil obtained from different sites and laboratory-made chloride soil were used as soil samples, and were stabilized using alkali-activated slag (AS). The unconfined compressive strength (UCS) of the stabilized soils was measured, and the microstructures of the stabilized soils were analyzed to investigate the strength variation and stabilization mechanism of AS-stabilized chloride saline soil.

\section{Materials and methods}

\subsection{Materials}

\subsubsection{Chloride saline soil samples}

\section{Soil obtained from the sites}

Two types of marine chloride saline soil samples were selected from reclaimed land in Tanggu and Tianjin-Binhai New Area, which are located around the Circum Bohai Bay area in eastern China, and two types of inland chloride saline soil samples were selected from two sites in the Qarhan salt lake field in Qinghai Province in western China. These four types of chloride saline soil samples are referred to as T1, T2, $\mathrm{X} 1$, and X2. The major physical-mechanical properties of each soil sample are shown in Table 1, and the major ion contents and $\mathrm{pH}$ values are shown in Table 2 .

Table 1 Major physical-mechanical properties of soil samples

\begin{tabular}{|c|c|c|c|c|}
\hline $\begin{array}{c}\text { Soil } \\
\text { sample ce }\end{array}$ & $\begin{array}{c}\text { Water } \\
\text { ntent, } \omega(\%\end{array}$ & $\begin{array}{l}\text { Density, } \\
\rho\left(\mathrm{g} / \mathrm{cm}^{3}\right)\end{array}$ & $\begin{array}{c}\text { Liquid limi } \\
\omega_{\mathrm{L}}(\%)\end{array}$ & $\begin{array}{c}\text { Plastic limit, } \\
\omega_{\mathrm{p}}(\%)\end{array}$ \\
\hline $\mathrm{T} 1$ & 81.8 & 1.44 & 43.9 & 22.6 \\
\hline $\mathrm{T} 2$ & 42.6 & 1.60 & 45.7 & 21.8 \\
\hline X1 & 21.1 & 2.01 & 25.6 & 17.3 \\
\hline $\mathrm{X} 2$ & 19.9 & 2.13 & 24.2 & 16.6 \\
\hline Soil & \multicolumn{4}{|c|}{ Grain size distribution (\%) } \\
\hline sample & $D^{*} \leq 2 \mu \mathrm{m}$ & \multicolumn{3}{|c|}{$2 \mu \mathrm{m}<D \leq 75 \mu \mathrm{m} 75 \mu \mathrm{m}<D<2000 \mu \mathrm{m}$} \\
\hline $\mathrm{T} 1$ & 52.0 & 48.0 & & 0 \\
\hline T2 & 50.1 & 49.8 & & 0.1 \\
\hline X1 & 16.9 & 60.4 & & 22.7 \\
\hline $\mathrm{X} 2$ & 0.5 & 22.1 & & 77.4 \\
\hline
\end{tabular}

${ }^{*} D$ : diameter

Table 2 Major ion contents and $\mathrm{pH}$ values of soil samples

\begin{tabular}{crrrrrrr}
\hline \multirow{2}{*}{$\begin{array}{c}\text { Soil } \\
\text { sample }\end{array}$} & \multicolumn{6}{c}{ Ion content (\%) } & $\mathrm{pH}$ \\
\cline { 2 - 6 } & $\mathrm{Cl}^{-}$ & $\mathrm{Na}^{+}$ & $\mathrm{SO}_{4}{ }^{2-}$ & $\mathrm{Ca}^{2+}$ & $\mathrm{Mg}^{2+}$ & value \\
\hline $\mathrm{T} 1$ & 1.32 & 1.23 & 0.26 & 0.01 & 0.01 & 7.78 \\
$\mathrm{~T} 2$ & 2.75 & 1.42 & 0.30 & 0.06 & 0.04 & 8.45 \\
$\mathrm{X} 1$ & 6.76 & 4.60 & 1.06 & 0.17 & 0.10 & 7.81 \\
$\mathrm{X} 2$ & 23.54 & 14.66 & 1.01 & 0.34 & 0.24 & 7.74 \\
\hline
\end{tabular}


2. Desalted soil (DS) samples

The DS samples were prepared by cleaning the salt in the chloride saline soil sample. The procedure for preparing the DS samples was as follows: First, the four chloride saline soil samples were naturally air-dried. Second, the dried soil samples were crushed down and sieved. Then, the soil samples were soaked in distilled water for $24 \mathrm{~h}$ and fully cleaned three times to remove the soluble salts in the soil. Finally, the soil samples were oven-dried, and water was added to maintain the water content at the same level as that of the soil sample obtained from the site. The DS samples were treated only to eliminate the salt in the soil, and the other properties of the soil were unchanged.

3. $\mathrm{NaCl}$ soil (NS) samples

This type of soil sample was prepared by adding some analytically pure $\mathrm{NaCl}$ to the DS samples, and the $\mathrm{NaCl}$ content added was the same as that of the soil sample obtained from the site.

\subsubsection{Laboratory-made chloride soil (ZS) samples}

The procedure for preparing the ZS samples was as follows: First, clay soil samples were prepared by mixing uncalcined kaolin clay and fine sand in a ratio of $8: 2$ (the water content was $40 \%$ ). Then, analytically pure $\mathrm{NaCl}$ (denoted by the chloride content) was added to the clay soil samples with different mass percentages. The fineness of the uncalcined kaolin clay was $10 \mu \mathrm{m}$, the sand particle size was less than $0.25 \mathrm{~mm}$, and the chloride content was expressed as the mass ratio of the chloride ions $\left(\mathrm{Cl}^{-}\right)$to that of dry soil. The ZS samples with different chloride contents were denoted as ZS1-ZS8, and the desalted soil sample without chloride was denoted as ZSO. The major physical-chemical properties of ZS0 are shown in Table 3, and the $\mathrm{Cl}^{-}$contents of the ZS-series are shown in Table 4.

Table 3 Major physical-chemical properties of ZS0

\begin{tabular}{cccccc}
\hline $\begin{array}{c}\text { Soil } \\
\text { sample }\end{array}$ & $\begin{array}{c}\text { Water } \\
\text { content, } \\
\omega(\%)\end{array}$ & $\begin{array}{c}\text { Density, } \\
\rho \\
\left(\mathrm{g} / \mathrm{cm}^{3}\right)\end{array}$ & $\begin{array}{c}\text { Liquid } \\
\text { limit, } \\
\omega_{\mathrm{L}}(\%)\end{array}$ & $\begin{array}{c}\text { Plastic } \\
\text { limit, }\end{array}$ & $\begin{array}{c}\mathrm{pH} \\
\omega_{\mathrm{p}}(\%)\end{array}$ \\
\hline VS0 & 40 & 1.67 & 44.5 & 23.1 & 7.26 \\
\hline
\end{tabular}

Table $4 \mathrm{Cl}^{-}$contents of $\mathrm{ZS}$-series

\begin{tabular}{cc||cc}
\hline Soil sample & $\mathrm{Cl}^{-}(\%)$ & Soil sample & $\mathrm{Cl}^{-}(\%)$ \\
\hline ZS0 & 0 & ZS5 & 6 \\
ZS1 & 0.5 & ZS6 & 10 \\
ZS2 & 1.5 & ZS7 & 15 \\
ZS3 & 3 & ZS8 & 20 \\
ZS4 & 5 & & \\
\hline
\end{tabular}

\subsubsection{Stabilizer}

AS was used as a stabilizer in this study. The major chemical components of the slag are shown in Table 5. The slag was analyzed using the ASTM C989-05 standards (ASTM International, 2005). The physical-mechanical properties of slag, including specific area (ASTM C989-05) and volume stability (GB/T 1346-2011) (AQSIQ, 2011), are shown in Table 6. Moreover, the slag activity index at $28 \mathrm{~d}$ was 100 Grade, as determined by ASTM C989-05. Analytically pure $\mathrm{Ca}(\mathrm{OH})_{2}$ was used as the alkaline activator, and the mixing mass ratio of $\mathrm{Ca}(\mathrm{OH})_{2}$ to slag was 1:9.

A Portland cement was used in this study (PC P6). The major chemical components of PC P6 are given in Table 5 and were determined according to the GB/T 176-2008 standards (AQSIQ, 2008). The physical-mechanical properties of PC P6, including specific area, setting time (GB/T 1346-2011), and volume stability (GB/T 1346-2011) (AQSIQ, 2011) are shown in Table 6. According to these results, the potential composition of PC P6, found using Bogue's formulas (ASTM C150-2012) (ASTM International, 2012), was as follows: $59 \% 3 \mathrm{CaO} \cdot \mathrm{SiO}_{2}\left(\mathrm{C}_{3} \mathrm{~S}\right), 0 \%$ $2 \mathrm{CaO} \cdot \mathrm{SiO}_{2}\left(\mathrm{C}_{2} \mathrm{~S}\right), 0 \% 3 \mathrm{CaO} \cdot \mathrm{Al}_{2} \mathrm{O}_{3}\left(\mathrm{C}_{3} \mathrm{~A}\right)$, and $30 \%$ $4 \mathrm{CaO} \cdot \mathrm{Al}_{2} \mathrm{O}_{3} \cdot \mathrm{Fe}_{2} \mathrm{O}_{3}\left(\mathrm{C}_{4} \mathrm{AF}\right)$. In a nutshell, the PC P6 is sulfate-resistant Portland cement (SRPC) as indicated by its ratio of $\mathrm{Al}_{2} \mathrm{O}_{3}$ to $\mathrm{Fe}_{2} \mathrm{O}_{3}$ being less than 0.64 and its $\mathrm{C}_{3} \mathrm{~A}$ content being 0 .

Table 5 Major chemical composition of slag and PC P6

\begin{tabular}{ccccc}
\hline \multirow{2}{*}{ Stabilizer } & \multicolumn{4}{c}{ Major chemical composition (\%) } \\
\cline { 2 - 5 } & $\mathrm{CaO}$ & $\mathrm{SiO}_{2}$ & $\mathrm{Al}_{2} \mathrm{O}_{3}$ & $\mathrm{MgO}$ \\
\hline Slag & 44.06 & 28.72 & 15.13 & 5.34 \\
PC P6 & 57.46 & 15.46 & 3.63 & 6.09 \\
\hline \hline \multirow{2}{*}{ Stabilizer } & \multicolumn{3}{c}{ Major chemical composition (\%) } \\
\cline { 2 - 5 } & $\mathrm{SO}_{3}$ & $\mathrm{Fe}_{2} \mathrm{O}_{3}$ & $\mathrm{Na}_{2} \mathrm{O}$ & $\mathrm{K}_{2} \mathrm{O}$ \\
\hline Slag & 3.81 & 0.83 & 0.20 & 0.47 \\
PC P6 & 0.75 & 13.50 & 0.36 & 0.24 \\
\hline
\end{tabular}

Table 6 Physical-mechanical properties of slag and PC P6

\begin{tabular}{cccccc}
\hline \multirow{2}{*}{$\begin{array}{c}\text { Stabi- } \\
\text { lizer }\end{array}$} & $\begin{array}{c}\text { Specific } \\
\text { area } \\
\left(\mathrm{m}^{2} / \mathrm{kg}\right)\end{array}$ & $\begin{array}{c}\text { Initial } \\
\text { setting }\end{array}$ & $\begin{array}{c}\text { Final set- } \\
\text { time }(\mathrm{min})\end{array}$ & $\begin{array}{c}\text { ting time } \\
(\mathrm{min})\end{array}$ & $\begin{array}{c}\text { Volume } \\
\text { stability }(\mathrm{mm})\end{array}$ \\
\cline { 5 - 6 } & & $0 \% \mathrm{Cl}^{-}$ & $5 \% \mathrm{Cl}^{-}$ \\
\hline Slag & 400 & - & - & 1.4 & 1.5 \\
PC P6 & 350 & 170 & 235 & 0.6 & 0.6 \\
\hline
\end{tabular}




\subsection{Testing of specimens}

Stabilized soil specimens were prepared by mixing the soil samples with the stabilizers at a dosage of $a_{\mathrm{w}}=10 \%$ (the mass ratio of dry stabilizer to wet soil), and with a water-stabilizer ratio (mass ratio of water to dry stabilizer) of 0.5 . The chloride saline soil samples were stabilized using PC P6 and AS, respectively. The ZS-series samples were stabilized using $\mathrm{AS}$, and corresponding to the soil samples ZS0-ZS8, the AS-stabilized ZS-series is denoted as GZS0GZS8 (GZS). All the specimens were cast as cubes with sides of $50 \mathrm{~mm}$; the specimens were demoulded after $24 \mathrm{~h}$ and cured in a standard curing chamber at a temperature of $(20 \pm 2){ }^{\circ} \mathrm{C}$ and a relative humidity of $95 \%$. After the stabilized soil specimens were standardly cured for a given curing time, the UCS of the stabilized soil specimens was measured, and the microstructure and hydration products of some specimens were tested by X-ray diffraction (XRD), energy-dispersive X-ray analysis (EDXA), thermal gravity-differential thermal gravity (TG-DTG), and ion concentration tests.

\subsubsection{UCS test}

The UCS of the stabilized soil specimens cured for different periods was tested according to standard ASTM D2166-13 (ASTM International, 2013). The UCS of stabilized soil was measured with an LQ-100S Pavement Material Strength Tester (China), and the loading rate was $1 \mathrm{~mm} / \mathrm{min}$.

\subsubsection{XRD}

A LabX-6000X XRD instrument manufactured by Rigaku (Japan) was used to analyze the type of hydrates present in the stabilized soils. Powder specimens were scanned from $3^{\circ}$ to $60^{\circ}$ at a speed of $4\left(^{\circ}\right) / \mathrm{min}$, with a step size of $0.02^{\circ}$. The procedure for preparing the powder specimens was as follows: First, the central portion of the stabilized soil specimens that completed the UCS test was selected and put in a vacuum drying oven. Then, the specimens were dried at $60{ }^{\circ} \mathrm{C}$ until a constant weight was reached. Finally, the specimens were ground to $200-400$ meshes and then dried and sealed for preservation.

\subsubsection{EDXA}

A GS3400-type scanning electron microscope (equipped with an energy spectroscopy system) pro- duced by British Camscan was used for EDXA. The procedure for sample preparation was as follows: First, the central portion of the stabilized soil specimens that completed the UCS test was selected and put in a vacuum drying oven, and the specimens were dried at $60{ }^{\circ} \mathrm{C}$ until a constant weight was reached. Then, a small block of the specimen with a flat surface was prepared. The surface area was about $10 \mathrm{~mm}$ $\times 10 \mathrm{~mm}$, and the thickness was about $1 \mathrm{~mm}$. A metal coating was sprayed using a vacuum coating machine, and, finally, the specimen was pasted with conductive adhesive and placed directly on the sample stage to be tested.

\subsubsection{TG-DTG}

A TG 209 F3-Tarsus thermal gravity analyzer produced by Netzsch (Germany) was used for the TG-DTG tests. The tests were performed in a temperature range of $50-400{ }^{\circ} \mathrm{C}$, and the heating rate was $10{ }^{\circ} \mathrm{C} / \mathrm{min}$. The preparation procedure for the TG-DTG test specimens was the same as that for the XRD test.

\subsubsection{Analysis of ion concentrations in pore solutions}

The extraction of the pore solution was performed on the basis of Wan et al. (2013)'s design as follows: The specimens wrapped in ninon were compressed by Barneyback's expression device at a rate of $0.2 \mathrm{kN} / \mathrm{s}$ until a load level of $500 \mathrm{kN}$ was attained. The load remained constant for $5 \mathrm{~min}$, and, under this applied load, the pore solution was squeezed out completely and could be collected in a glass bottle. Then the extracted pore solution was filtered through an ashless filter, and the ionic concentrations in the expressed pore solution were measured according to the testing code JTJ 270-98 (MOT, 1998).

\section{Results and discussion}

\subsection{UCS of stabilized soil}

The UCS of four types of chloride saline soil samples stabilized by PC P6 and AS after curing for $28 \mathrm{~d}$ is shown in Table 7 .

Table 7 shows that the UCS values of four soil samples obtained from the site stabilized by AS are higher than those of samples stabilized by PC P6. Furthermore, the UCS values of AS stabilized X2, 
which have the highest salinity and chloride content of the four samples, are about four times higher than those of the sample stabilized by PC P6. These results indicate that $\mathrm{AS}$ is more effective than $\mathrm{PC} \mathrm{P} 6$ for stabilizing chloride saline soil (Talero and Trusilewicz, 2012). At the same time, the UCS values of the DS samples stabilized by AS are lower than those of the corresponding soil samples obtained from sites; however, the UCS values of the DS samples stabilized by PC P6 are higher than those of the corresponding soil samples. These results indicate that the salt in the soil is a notable factor that influences the UCS values of the stabilized soil. Salt in the soil is beneficial for AS-stabilized soil but harmful for PC P6-stabilized soil. Therefore, AS is a suitable stabilizer that can be applied to stabilize chloride saline soil.

Table 7 also shows that the ratio of UCS of AS/PC P6 of soil samples obtained from sites increases with the increase of salinity and chloride content of the soil and that the ratio of UCS of AS/PC P6 of DS samples is maintained in the range of 1.35 -1.45 . These values indicate that the salt in the soil may be the main factor that affects the UCS values of stabilized soil rather than other properties of the soil.

Table 7 28-d UCS values of stabilized soil

\begin{tabular}{cccc}
\hline \multirow{2}{*}{ Soil sample } & \multicolumn{2}{c}{ 28-d UCS (MPa) } & Ratio of UCS, \\
\cline { 2 - 3 } & AS & PC P6 & ASC P6 \\
\hline T1 & 1.10 & 0.65 & 1.69 \\
T2 & 2.65 & 1.28 & 2.07 \\
X1 & 2.41 & 0.84 & 2.87 \\
X2 & 4.52 & 1.15 & 3.93 \\
T1-DS & 1.07 & 0.77 & 1.39 \\
T2-DS & 2.39 & 1.76 & 1.36 \\
X1-DS & 1.89 & 1.35 & 1.40 \\
X2-DS & 3.29 & 2.30 & 1.43 \\
T1-NS & 1.10 & - & - \\
T2-NS & 2.66 & - & - \\
X1-NS & 2.36 & - & - \\
X2-NS & 4.47 & - & - \\
\hline
\end{tabular}

DS and NS represent desalted soil and $\mathrm{NaCl}$ soil of the $\mathrm{T} 1, \mathrm{~T} 2, \mathrm{X} 1$, and $\mathrm{X} 2$, respectively

The UCS values of AS-stabilized NS samples are also shown in Table 7 and are similar to those for AS-stabilized soil samples obtained from sites. The only difference between these two soil samples is that the NS sample only contains $\mathrm{NaCl}$ but the other sample contains several salts, such as $\mathrm{NaCl}, \mathrm{Na}_{2} \mathrm{SO}_{4}$, and $\mathrm{CaSO}_{4}$. This difference has no notable influence on the UCS of the stabilized soil, which indicates that the $\mathrm{NaCl}$ in chloride saline soil is the main factor affecting the UCS of AS-stabilized soil.

The relationship between the UCS of GZS after different curing times and the chloride content in the soil is shown in Fig. 1. Fig. 1 shows that the UCS of GZS after different curing times increases with increase of the chloride content in the soil. Through calculation, the UCS values of GZS 8 are $38 \%$ and $42 \%$ greater than those of GZS0 after $28 \mathrm{~d}$ and $60 \mathrm{~d}$ of curing, respectively. Therefore, $\mathrm{NaCl}$ increases the UCS of GZS. $\mathrm{NaCl}$ in the soil is beneficial for AS-stabilized soil.

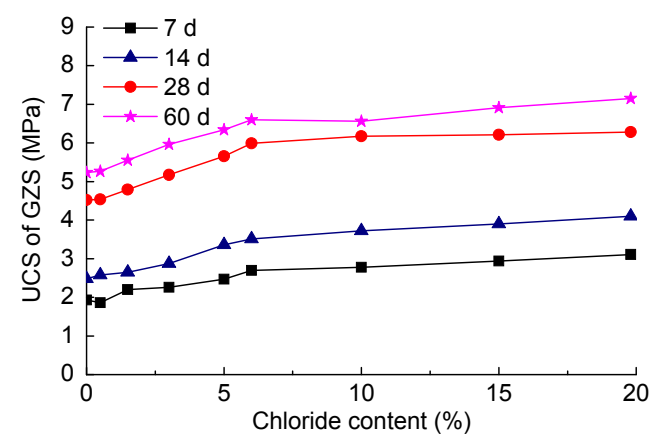

Fig. 1 UCS of GZS for different chloride contents

\subsection{XRD analysis}

The XRD patterns of stabilized soil specimens GZS0, GZS3, GZS5, and GZS8 after curing for $28 \mathrm{~d}$ are shown in Fig. 2a, and the XRD spectra of soil samples ZS3, ZS8, GZS3, and GZS8 are shown in Fig. 2b. The main diffraction peaks for Friedel's salt (Fs), calcium silicate hydrate $(\mathrm{CSH})$, and $\mathrm{NaCl}$ are indicated in this figure. The relative amounts of constituents in the stabilized soil samples can be determined using the semi-quantitative procedure suggested by Bish (1993). Using this method, the generation mass percentage of Fs and the consumption mass percentage of $\mathrm{NaCl}$ in stabilized soil samples were calculated as shown in Fig. 3.

As shown in Figs. 2 and 3, a new chloride hydrate, $3 \mathrm{CaO} \cdot \mathrm{Al}_{2} \mathrm{O}_{3} \cdot \mathrm{CaCl}_{2} \cdot 10 \mathrm{H}_{2} \mathrm{O}$ (Fs), appears in GZS3, GZS5, and GZS8, and an increase of the chloride content in GZS enhances the generation mass percentage of Fs and the consumption mass percentage of $\mathrm{NaCl}$. Furthermore, the characteristic 
peak of a cementitious hydrate, $\mathrm{CSH}$, also increased with an increase of the chloride content.
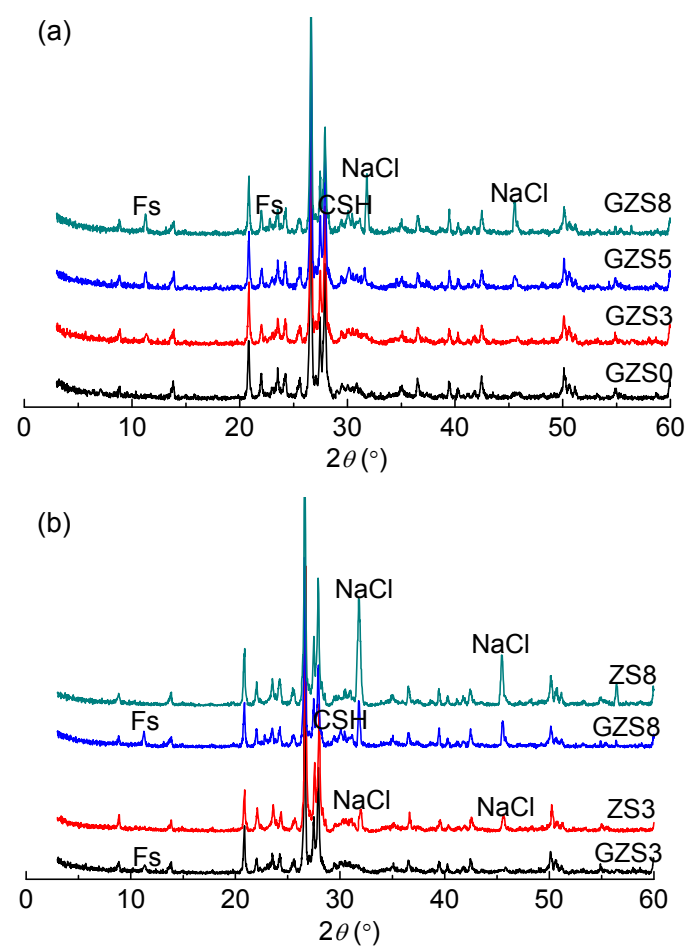

Fig. 2 X-ray diffraction spectra of stabilized soils (a) Specimens GZS0, GZS3, GZS5, and GZS8 after curing for 28 d; (b) Specimens ZS3, ZS8, GZS3, and GZS8

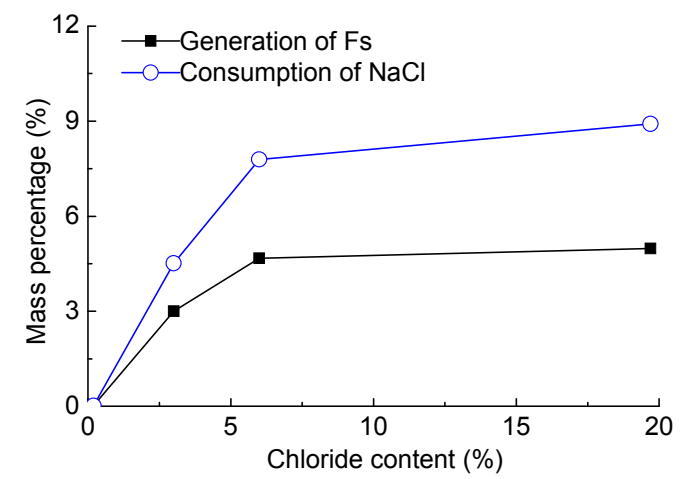

Fig. 3 Relationship between the chloride content and the mass percentage of $\mathrm{Fs}$ and $\mathrm{NaCl}$

\subsection{Analysis of ionic concentrations in pore solutions}

The total chloride concentration, dissolved chloride concentration, bound chloride concentration, dissolved hydroxyl concentration, and $\mathrm{pH}$ value of the pore solutions of GZS after curing for $28 \mathrm{~d}$ are shown in Table 8; the total chloride concentration is equal to the sum of the dissolved chloride concentration and the bound chloride concentration and $\mathrm{pH}=14+\lg x$, where $x$ is the dissolved hydroxyl concentration.

The concentrations of bound chloride and dissolved hydroxyl increase with an increase of the total chloride concentration in the pore solutions, and the $\mathrm{pH}$ value also increases. These results can be explained by the fact that the dissolved chloride in GZS is bound in a chloride hydrate, and, at the same time, hydroxyl free radicals are generated. According to the XRD results, the chloride hydrate is Fs, and the amount of Fs increases with the consumption of $\mathrm{NaCl}$.

Table 8 Total, dissolved, and bound chloride concentrations, dissolved hydroxyl concentration and $\mathrm{pH}$ value in GZS

\begin{tabular}{|c|c|c|c|c|c|}
\hline \multirow[b]{2}{*}{ Specimen } & \multicolumn{4}{|c|}{ Ion content $(\mathrm{mmol} / \mathrm{L})$} & \multirow{2}{*}{$\begin{array}{c}\mathrm{pH} \\
\text { value }\end{array}$} \\
\hline & $\begin{array}{c}\text { Total } \\
\text { chloride }\end{array}$ & $\begin{array}{c}\text { Dissolved } \\
\text { chloride }\end{array}$ & $\begin{array}{c}\text { Bound } \\
\text { chloride }\end{array}$ & $\begin{array}{c}\text { Dissolved } \\
\text { hydroxyl }\end{array}$ & \\
\hline GZS0 & 24 & 9 & 15 & 27 & 12.43 \\
\hline GZS3 & 2028 & 592 & 1436 & 68 & 12.83 \\
\hline GZS5 & 3972 & 2115 & 1857 & 88 & 12.94 \\
\hline GZS8 & 13380 & 11179 & 2201 & 96 & 12.98 \\
\hline
\end{tabular}

Reactive alumina, $\mathrm{Al}_{2} \mathrm{O}_{3}{ }^{{ }^{\mathrm{r}}-}$, in natural and artificial pozzolans (Trusilewicz et al., 2012) can react with $\mathrm{NaCl}$ to form $\mathrm{Fs}$ at room temperature (Talero et al., 2011). The stabilizer slag contains a high content of $\mathrm{Al}_{2} \mathrm{O}_{3}$. The form of reactive alumina present is not like $\mathrm{Al}_{2} \mathrm{O}_{3}{ }^{\mathrm{r}-}$ (Gutierrez et al., 1998), but like $\mathrm{CaO} \cdot \mathrm{Al}_{2} \mathrm{O}_{3}$ (CA). Thus, in this study, Fs may be formed according to the following equation:

$$
\begin{array}{r}
\mathrm{CaO} \cdot \mathrm{Al}_{2} \mathrm{O}_{3}(\mathrm{CA})+\mathrm{Ca}(\mathrm{OH})_{2}+2 \mathrm{NaCl}+2 \mathrm{CaO}+10 \mathrm{H}_{2} \mathrm{O} \\
=3 \mathrm{CaO} \cdot \mathrm{Al}_{2} \mathrm{O}_{3} \cdot \mathrm{CaCl}_{2} \cdot 10 \mathrm{H}_{2} \mathrm{O}(\mathrm{Fs})+2 \mathrm{NaOH} .
\end{array}
$$

According to the volume stability test results in Table 6, the Fs, unlike the ettringite, is non-expansive (Talero et al., 2011), and it has the ability to fill the macroporous, porous, microporous, and capillary systems in the PC mass (Talero, 2012), and in the GZS series mass as well. Furthermore, $\mathrm{NaOH}$ is formed from $\mathrm{NaCl}$. However, it remains dissolved in the liquid phase of the GZS series, increasing the alkalinity of their pore solutions, and making Fs stable. Hence, the filling-in effect of Fs is the main reason for the improved mechanical strength of the 
GZS. In short, Fs increases the strength directly, whereas $\mathrm{NaOH}$ does the same, but, indirectly.

\subsection{EDXA analysis}

The microstructure of 28-d GZS8 at Point 1 and Point 2 observed using spot mode analysis is shown in Fig. 4. EDXA results for Point 1 and Point 2 are listed in Table 9.

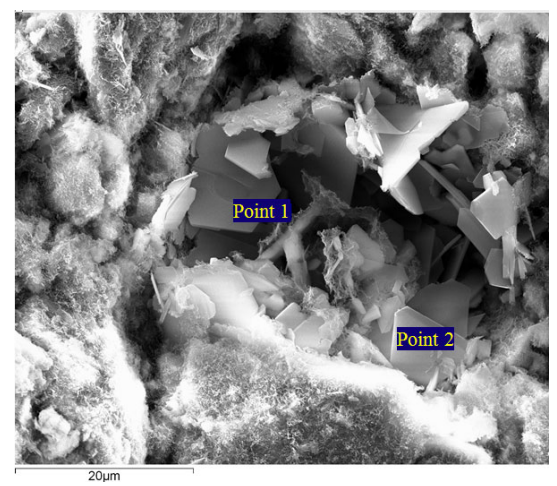

Fig. 4 Microstructure of GZS8

Table 9 EDXA analysis of GZS8

\begin{tabular}{ccccccc}
\hline \multirow{2}{*}{ Point } & \multicolumn{6}{c}{ Mass percentage of element (\%) } \\
\cline { 2 - 7 } & $\mathrm{O}$ & $\mathrm{Ca}$ & $\mathrm{C}$ & $\mathrm{Cl}$ & $\mathrm{Al}$ & $\mathrm{Si}$ \\
\hline 1 & 50.18 & 17.76 & 8.58 & 8.10 & 7.31 & 7.10 \\
2 & 52.11 & 16.67 & 9.83 & 7.90 & 6.20 & 5.67 \\
\hline
\end{tabular}

As shown in Fig. 4, the morphology of the microstructure at Point 1 and Point 2 is plate-like crystals. The mass ratios of $\mathrm{Ca}: \mathrm{Cl}: \mathrm{Al}$ at Point 1 and Point 2 were calculated, and the values are close to that of Fs, which could indicate that the plate-like crystals in Fig. 4 are Fs. According to Talero (2012), the morphology of Fs is plate-like (or flat hexagonal) crystals. As shown in Fig. 4, many plate-like crystals are interspersed in the pore space of the soil particles. These crystals can squeeze and fill the pores in the stabilized soil and make the structure of the stabilized soil denser, which may be an important cause of the increase in the strength of GZS.

\subsection{TG-DTG analysis}

The results of TG-DTG tests of stabilized soil specimens GZS0, GZS3, GZS5, and GZS8 after curing for $28 \mathrm{~d}$ are shown in Fig. 5, which shows the TG-DTG curve between $50^{\circ} \mathrm{C}$ and $400{ }^{\circ} \mathrm{C}$.

The presence of $\mathrm{CSH}$ (main weight loss at around $50-200{ }^{\circ} \mathrm{C}$ ) and Fs (weight loss at around
$300-400{ }^{\circ} \mathrm{C}$ ) is confirmed by the TG-DTG data in Fig. 5. Using the Proteus analysis software, the generation mass percentage of Fs and CSH in GZS was calculated. The mass percentages of Fs and $\mathrm{CSH}$ in GZS0 are $0.1 \%$ and $9.2 \%$, respectively, and the mass percentages of Fs and CSH in GZS8 are 5.1\% and $11.8 \%$, respectively, which quantitatively indicates that more CSH and Fs are formed in GZS with a high chloride content, as indicated by the derivative DTG data. Combining the results in Table 8 and Eq. (1), we can find that the $\mathrm{pH}$ value of the pore solution in GZS increases with the increase of chloride content and the amount of $\mathrm{NaOH}$. The increase in $\mathrm{pH}$ value promotes the hydration of the slag (Fernández-Jiménez and Puertas, 2003). Thus, more CSH can be produced in stabilized soil. Therefore, the greater amount of $\mathrm{CSH}$ produced in GZS may be another important cause of the increase in the strength of GZS.

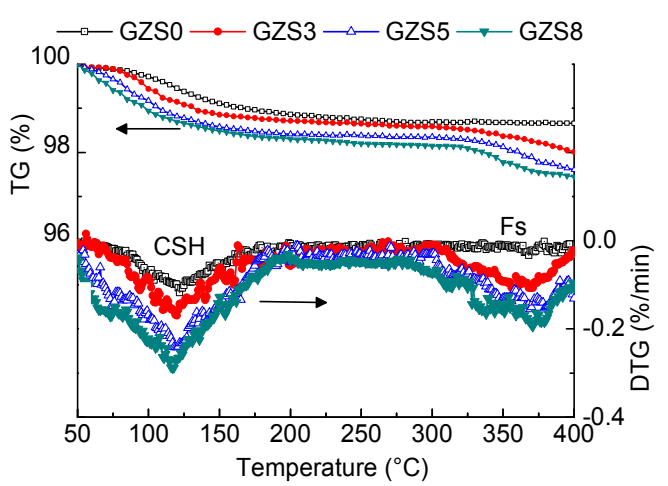

Fig. 5 TG-DTG data of GZS

In summary, the UCS of GZS increases with the increase of the chloride content because of the formation of Fs and $\mathrm{NaOH}$ in the soil. The generation of Fs can fill the pores in the stabilized soil, and the generation of $\mathrm{NaOH}$ can increase the generation of $\mathrm{CSH}$. These two factors work together to increase the UCS of GZS.

\subsection{Correlation between UCS increase and chlo- ride content}

The relation between the increase rate of the 28-d UCS $\left(\varepsilon_{q u}\right)$ of GZS and the chloride content $(t)$ of the soil is shown in Fig. 6. The calculation of $\varepsilon_{q u}$ is given by

$$
\varepsilon_{q u}=\frac{q_{u, L}-q_{u, 0}}{q_{u, 0}} \times 100 \%,
$$


where $\varepsilon_{q u}$ represents the rate of increase of the 28-d UCS of AS-stabilized chloride saline soil, and $q_{u, L}$ and $q_{u, 0}$ represent the 28-d UCS of AS-stabilized chloride saline soil and the 28-d UCS of AS-stabilized desalted soil, respectively.

To analyze the relation between the $\varepsilon_{q u}$ of GZS and the chloride content $(t)$ of the soil by regression analysis, the regression curve is depicted in Fig. 6 and is expressed as

$$
\varepsilon_{q u}=0.0103 t^{3}-0.4911 t^{2}+7.6506 t-6.5792 .
$$

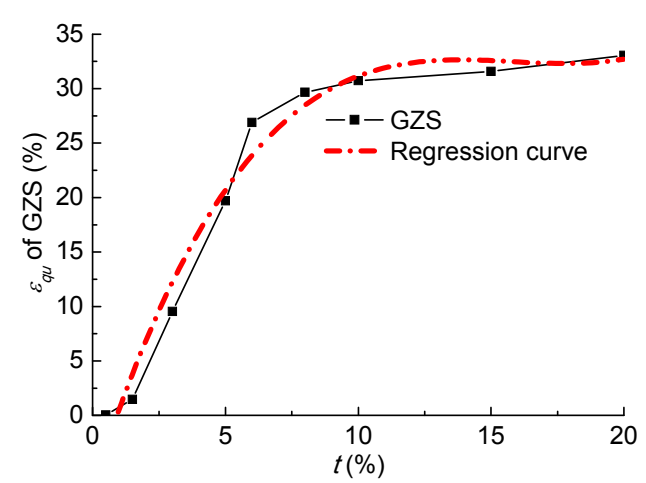

Fig. 6 Relation between $\varepsilon_{q u}$ of GZS and chloride content in soil

As shown in Fig. 6, $\varepsilon_{q u}$ is greater when the chloride content is lower than $6 \%$, and is lower when the chloride content is higher than $6 \%$, which is similar to the curve trends in Figs. 1 and 3. The limited $\mathrm{Al}_{2} \mathrm{O}_{3}$ in the slag may cause these trends, and a chloride content of $6 \%$ may be the critical point of consumption of $\mathrm{Al}_{2} \mathrm{O}_{3}$. When the chloride content of soil is lower than $6 \%$, the alumina-bearing phases in the slag may be abundant according to Eq. (1) and generate more Fs and $\mathrm{NaOH}$. These hydrates significantly enhance the 28-d UCS of stabilized soil, so $\varepsilon_{q u}$ is fast. When the chloride content of soil is higher than $6 \%$, the alumina-bearing phases in the slag may be inadequate for the reaction. Thus, the amounts of Fs and $\mathrm{NaOH}$ generated decrease, which affects the enhancement of the 28-d UCS of stabilized soil, so $\varepsilon_{q u}$ declines.

The relationship between $\varepsilon_{q u}$ and $t$ is well expressed by Eq. (3). Eq. (3) can conveniently predict $\varepsilon_{q u}$ of AS-stabilized chloride saline soil samples with different chloride contents. To verify the effectiveness of Eq. (3), the measured values and the predicted values of $\varepsilon_{q u}$ of AS-stabilized T1, T2, X1, X2, and NS samples were calculated according to Eqs. (2) and (3), respectively. The predicted values are plotted against the measured values in Fig. 7. We can see that the predicted values are close to the measured values, and the maximum deviation between the predicted values and the measured values is below $6 \%$, which indicates that the prediction model in Eq. (3) is very accurate. Therefore, the prediction model in Eq. (3) can be used as a reference for AS-stabilized chloride saline soil.

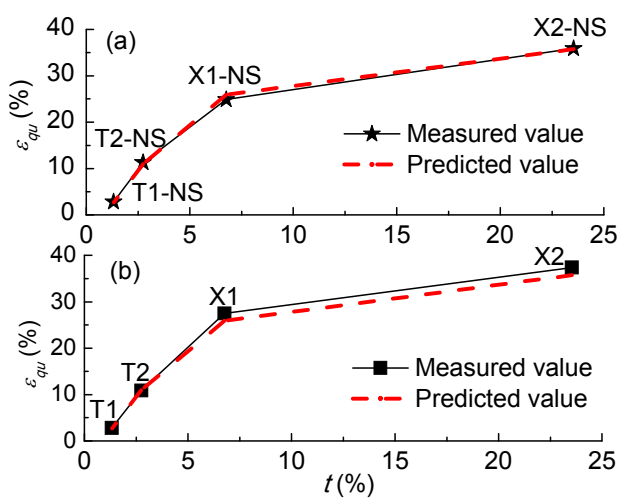

Fig. 7 Comparison of the predicted values and measured values of $\varepsilon_{q u}$ of AS-stabilized NS (a) and T1, T2, X1, X2 (b)

\section{Conclusions}

Based on the results described in this investigation, the following conclusions can be drawn:

1. The strength of AS-stabilized chloride saline soils is higher than that of PC P6-stabilized soils, which was the only type of cement used in the study. AS is thus a suitable stabilizer that can be used to stabilize chloride saline soil.

2. The strengths of AS-stabilized soil samples obtained from sites and NS samples are higher than those of the corresponding AS-stabilized DS samples. $\mathrm{NaCl}$ is the most important factor affecting the strength of AS-stabilized chloride saline soil.

3. The strength of GZS increases with increase of the chloride content in the soil samples, and $\mathrm{NaCl}$ in the GZS is beneficial for AS-stabilized soil.

4. Fs and $\mathrm{NaOH}$ are generated by the reaction of $\mathrm{NaCl}$ and $\mathrm{CA}$ in the slag. Fs can fill the pores in the stabilized soil and make its structure denser. The generation of $\mathrm{NaOH}$ can increase the alkalinity of the pore solution and promote the hydration of slag, which generates more $\mathrm{CSH}$ and enhances the cementation of the soil. These two effects together enhance the stability of GZS. 
5. The relationship between the increase rate of 28-d UCS of AS-stabilized chloride saline soil and the chloride content of the soil was obtained by regression analysis, and the model can provide a reference for AS-stabilized chloride saline soil.

\section{References}

AQSIQ (Administration of Quality Supervision, Inspection and Quarantine), 2008. Methods for Chemical Analysis of Cement, GB/T 176-2008. National Standards of People's Republic of China (in Chinese).

AQSIQ (Administration of Quality Supervision, Inspection and Quarantine), 2011. Test Methods for Water Requirement of Normal Consistency, Setting Time and Soundness of the Portland Cement, GB/T 1346-2011. National Standards of People's Republic of China (in Chinese).

ASTM (American Society for Testing and Materials) International, 2005. Standard Specification for Ground Granulated Blast Furnace Slag for Use in Concrete and Mortars, ASTM C989-05. ASTM International, West Conshohocken, PA, USA.

ASTM (American Society for Testing and Materials) International, 2012. Standard Specification for Portland Cement, ASTM C150-2012. ASTM International, West Conshohocken, PA, USA.

ASTM (American Society for Testing and Materials) International, 2013. Standard Test Method for Unconfined Compressive Strength of Cohesive Soil, ASTM D2166-13. ASTM International, West Conshohocken, PA, USA.

Bish, D.L., 1993. Rietveld refinement of the kaolinite structure at 1.5 K. Clays and Clay Minerals, 41(6):738-744. http://dx.doi.org/10.1346/CCMN.1993.0410613

Chen, R.P., Drnevich, V.P., Daita, R.K., 2009. Short-term electrical conductivity and strength development of lime kiln dust modified soils. Journal of Geotechnical and Geoenvironmental Engineering, 135(4):590-594. http://dx.doi.org/10.1061/(ASCE)1090-0241(2009)135:4 (590)

Fernández-Jiménez, A., Puertas, F., 2003. Effect of activator mix on the hydration and strength behaviour of alkaliactivated slag cements. Advances in Cement Research, 15(3):129-136. http://dx.doi.org/10.1680/adcr.2003.15.3.129

Gutierrez, R., Delvasto, S., Talero, R., 1998. Performance of GGBS cements. Journal of Solid Waste Technology and Management, 25(2):112-115.

Higgins, D.D., 2005. Soil Stabilisation with Ground Granulated Blastfurnace Slag. Technical Report, UK Cementitious Slag Makers Association, Oxted.

Luo, H.S., 2009. Study on Comprehensive Properties of Curing Chlorine Saline Soil in Tianjin Binhai New Area. MS
Thesis, Chang'an University, Xi'an, China (in Chinese). MOT (Ministry of Transport of the People's Republic of China), 1998. Testing Code of Concrete for Port and Waterway Engineering, JTJ 270-98. Industry Standards of People's Republic of China (in Chinese).

Rajasekaran, G., 2005. Sulphate attack and ettringite formation in the lime and cement stabilized marine clays. Ocean Engineering, 32(8-9):1133-1159. http://dx.doi.org/10.1016/j.oceaneng.2004.08.012

Shihata, S.A., Baghdadi, Z.A., 2001. Long-term strength and durability of soil cement. Journal of Materials in Civil Engineering, 13(3):161-165. http://dx.doi.org/10.1061/ (ASCE)0899-1561(2001)13:3(161)

Talero, R., 2012. Synergic effect of Friedel's salt from pozzolan and from OPC co-precipitating in a chloride solution. Construction and Building Materials, 33(8): 164-180. http://dx.doi.org/10.1016/j.conbuildmat.2011.12.040

Talero, R., Trusilewicz, L., 2012. Morphological differentiation and crystal growth form of Friedel's salt originated from pozzolan and Portland cement. Industrial \& Engineering Chemistry Research, 51(38):12517-12529. http://dx.doi.org/10.1021/ie301671z

Talero, R., Trusilewicz, L., Delgado, A., et al., 2011. Comparative and semi-quantitative XRD analysis of Friedel's salt originating from pozzolan and Portland cement. Construction and Building Materials, 25(5):2370-2380. http://dx.doi.org/10.1016/j.conbuildmat.2010.11.037

Tasong, W.A., Wild, S., Tilley, R.J.D., 1999. Mechanisms by which ground granulated blastfurnace slag prevents sulphate attack of lime-stabilised kaolinite. Cement and Concrete Research, 29(7):975-982. http://dx.doi.org/10.1016/S0008-8846(99)00007-1

Trusilewicz, L., Fernández-Martínez, F., Rahhal, V., et al., 2012. TEM and SAED characterization of metakaolin. Pozzolanic activity. Journal of the American Ceramic Society, 95(9):2989-2996.

http://dx.doi.org/10.1111/j.1551-2916.2012.05325.x

Valls, S., Vàzquez, E., 2000. Stabilisation and solidification of sewage sludge with Portland cement. Cement and Concrete Research, 30(10):1671-1678. http://dx.doi.org/10.1016/S0008-8846(00)00363-X

Wan, X.M., Wittmann, F.H., Zhao, T.J., et al., 2013. Chloride content and $\mathrm{pH}$ value in the pore solution of concrete under carbonation. Journal of Zhejiang UniversitySCIENCE A (Applied Physics \& Engineering), 14(1): 71-78. http://dx.doi.org/10.1631/jzus.A1200187

Wang, J.W.H., Kremmydas, A.H., 1970. Use of sodium chloride in reducing shrinkage in montmorillonitic soilcement. Highway Research Board, 315(11):81-90.

Wattanasanticharoen, E., 2004. Experimental Studies to Address Volume Change Behaviors of Chemically Treated Sulfate Bearing Soils. PhD Thesis, The University of 
Texas at Arlington, Texas, USA.

Wild, S., Kinuthia, J.M., Jones, G.I., et al., 1998. Effects of partial substitution of lime with ground granulated blast furnace slag (GGBS) on the strength properties of lime-stabilised sulphate-bearing clay soils. Engineering Geology, 51(1):37-53. http://dx.doi.org/10.1016/S0013-7952(98)00039-8

Xing, H.F., Yang, X.M., Xu, C., 2009. Strength characteristics and mechanisms of salt-rich soil-cement. Engineering Geology, 103(1-2):33-38. http://dx.doi.org/10.1016/j.enggeo.2008.07.011

Yang, J.S., 2008. Development and prospect of the research on salt-affected soils in China. Acta Pedologica Sinica, 45(5):837-845 (in Chinese).

Yang, X.M., 2006. Microstructure and Mechanism Research on Cement Stabilized Salt-rich Clay. MS Thesis, Tongji University, Shanghai, China (in Chinese).

Zhang, D.W., Cao, Z.G., Fan, L.B., et al., 2014. Evaluation of the influence of salt concentration on cement stabilized clay by electrical resistivity measurement method. Engineering Geology, 170(6):80-88.

http://dx.doi.org/10.1016/j.enggeo.2013.12.010

\section{中文概要}

题 目: 矿渣固化氯盐渍土强度变化规律试验研究

目 的: 探讨矿渣固化氯盐渍土强度变化规律及作用机 理, 为氯盐渍土有效固化提供依据。

创新点: 评价矿渣固化高含盐量氯盐渍土的效果, 分析矿 渣固化氯盐渍土固化机理, 提出具有一定适用性 的拟合关系式。

方 法: 通过固化土无侧限抗压强度试验、X 射线衍射、 能谱分析、热重及液相离子浓度测试对固化氯盐 渍土强度及微观结构进行分析。

结 论: 1. 氯化钠是影响矿渣固化氯盐渍土强度的主因;

2. 矿渣固化氯盐渍土强度随土中含氯量增加而 增强, 铝酸钲与氯化钠反应生成的水化氯铝酸钲 填充孔隙及氢氧化钠提高液相碱度是增强固化 土强度的主因; 3. 通过固化土强度增量曲线拟合 分析, 得到矿渣固化氯盐渍土强度增量与含氯量 关系式。

关键词: 氯盐渍土; 碱激发矿渣; 固化土; 强度; 水化氯 铝酸钻; 氢氧化钠 